\title{
Dietary Available Phosphorus Affected Growth Performance, Body Composition, and Hepatic Antioxidant Property of Juvenile Yellow Catfish Pelteobagrus fulvidraco
}

\author{
Qin Tang, ${ }^{1}$ Chunfang Wang, ${ }^{1}$ Congxin Xie, ${ }^{1}$ Jiali Jin, ${ }^{1}$ and Yanqing Huang ${ }^{2}$ \\ ${ }^{1}$ College of Fisheries, Huazhong Agricultural University, Wuhan 430070, China \\ ${ }^{2}$ East China Sea Fisheries Research Institute, Chinese Academy of Fishery Sciences, Shanghai 200090, China \\ Correspondence should be addressed to Chunfang Wang, cfwang@mail.hzau.edu.cn
}

Received 7 April 2012; Accepted 6 June 2012

Academic Editors: D. Benke and V. Dilis

Copyright ( $) 2012$ Qin Tang et al. This is an open access article distributed under the Creative Commons Attribution License, which permits unrestricted use, distribution, and reproduction in any medium, provided the original work is properly cited.

\begin{abstract}
An 8-week feeding trial was carried out with juvenile yellow catfish to study the effects of dietary available phosphorus (P) on growth performance, body composition, and hepatic antioxidant property. Six pellet diets were formulated to contain graded available P levels at $0.33,0.56,0.81,1.15,1.31$, and $1.57 \%$ of dry matter, respectively. Triplicate tanks with each tank containing 60 juveniles $(3.09 \pm 0.03 \mathrm{~g})$ were fed one of the six experimental diets for 8 weeks. Specific growth rate, feeding rate, and protein efficiency ratio were significantly higher at $0.81 \%$ dietary available P. Efficiency of P utilization distinctly decreased with increasing $\mathrm{P}$ level. Body lipid content significantly decreased while body ash and feces $\mathrm{P}$ content significantly increased with increasing $\mathrm{P}$ level. Quadratic regression analysis indicated that vertebrae P content was maximized at $1.21 \%$ dietary available P. Fish fed $1.57 \%$ dietary available $\mathrm{P}$ had highest activity of hepatic superoxide dismutase and catalase and malonaldehyde content. In conclusion, decreasing dietary available $\mathrm{P}$ increased $\mathrm{P}$ utilization efficiency and body lipid content while decreased vertebrae P content. Juvenile yellow catfish were subjected to oxidative damage under the condition of high dietary P content (1.57\%), and the damage could not be eradicated by their own antioxidant defense system.
\end{abstract}

\section{Introduction}

Phosphorus (P) is an important constituent of nucleic acids and cell membranes and is directly involved in all energyproducing cellular reactions $[1,2]$. Fish must obtain $\mathrm{P}$ from their food because of the low concentration of phosphate in natural waters [3]. P deficiency or P excess could probably affect the production of ATP, the synthesis of nucleic acids, and the complement of cell membranes, thus cause anorexia, transient lethargy, reduced growth, and dark coloration [4]. In most fish, the main signs of $\mathrm{P}$ deficiency include poor growth, poor feed efficiency, and bone mineralization [1].

Phosphorus deficiency enhanced lipid peroxidation and induced oxidative stress in plants [5], such as, bean [6], barley [7], and oilseed rape [8]. With the decrease of inorganic phosphate concentration in tissues, lipid peroxidation increased in cells [6]. Normally, generation of reactive oxygen species (ROS) is kept under control by antioxidant defense system that includes antioxidative enzymes, superoxide dismutase (SOD), catalase (CAT), peroxidase (POD), and glutathione peroxidase (GPX) and enzymes of HalliwellAsada pathway and antioxidative molecules: ascorbates, $\alpha$ tocopherol, carotenoids, flavonoids, and glutathione [911]. Overproduction of ROS results in oxidative stress, a deleterious process that can be an important mediator of damage to cell structures, including lipids and membranes, proteins, and DNA [12]. In the process of eliminating the free radicals, SOD, GSH-Px, and CAT are the major indirect free radical scavengers [12]. In unfavorable circumstance, the balance between the activities and the intracellular levels of these antioxidants is broken, and the imbalance will result in the accumulation of malonaldehyde (MDA) and finally lead to oxidative damage to cell [13].

Therefore, appropriate $\mathrm{P}$ is critical for organisms to maintain both structural and functional roles and to form an intricate and interwoven system regulating the healthy 
functioning [5]. P starvation is an abiotic stress that imposes an oxidative stress in plant root cells [6]. However, there was no clear report about the relationship between dietary $\mathrm{P}$ deficiency or $\mathrm{P}$ excess and oxidative responses in animals. Three types of metabolic control of oxidative metabolism observed in the various living tissues of animals had been reported: in skeletal muscle by $\mathrm{ADP}$ (or Pi/phosphocreatine), in cardiac tissue a coordinated control of substrate delivery that may involve $\mathrm{Ca}^{2+}$ and inorganic $\mathrm{P}$ control of $\mathrm{NADH}$, and control of $\mathrm{O}_{2}$ delivery [14]. Also, in rheumatoid arthritis patients, oxidative metabolism within the cell had been altered and oxygen free radicals were generated, which altered calcium and phosphorus levels in skeletal muscle cells [15].

Yellow catfish (Pelteobagrus fulvidraco) is a freshwater species native to Asian-Pacific waters, which is now becoming one of the major commercial species cultured by farmers in China. The annual production of yellow catfish reached 163,556 tons in the year of 2009, an increase of $21.65 \%$ over the year 2008 [16]. Most farmers use commercial feed to produce high output. However, these feeds are usually high in phosphorus content (about 20 to $25 \mathrm{~kg} \mathrm{Ca}\left(\mathrm{H}_{2} \mathrm{PO}_{4}\right)_{2} \cdot \mathrm{H}_{2} \mathrm{O}$ per ton feed). Large amounts of uneaten feed and feces released into the aquatic environment lead to eutrophication and cause a serious threat to the sustainable aquaculture of this species. $\mathrm{P}$ is the limiting nutrient for algae growth in freshwater ecosystem [17]. The effect of $\mathrm{P}$ is immediate and broad, causing both environmental concern and possible economic inefficiencies in the production systems due to increased costs associated with the biological and chemical processing of the waste [1].

Therefore, a need exists to determine the effects of dietary $\mathrm{P}$ content on fish performance and health functioning in the aquaculture setting, to balance the desire for high fish production with protection of the aquatic environment. Little research on dietary $\mathrm{P}$, especially hepatic antioxidant property under dietary P stress, has been conducted on yellow catfish. In the present study, six diets were formulated to contain low to high levels of $\mathrm{P}$ by adding $\mathrm{Ca}\left(\mathrm{H}_{2} \mathrm{PO}_{4}\right)_{2} \cdot \mathrm{H}_{2} \mathrm{O}$ into the basal diet. $\mathrm{Ca}\left(\mathrm{H}_{2} \mathrm{PO}_{4}\right)_{2} \cdot \mathrm{H}_{2} \mathrm{O}$ was chosen as the source of $\mathrm{P}$ due to two reasons: first, reports showed that dietary calcium concentration or calcium-phosphorus $(\mathrm{Ca} / \mathrm{P})$ imbalance has no effect on $\mathrm{P}$ requirement of catfish [18-20]; second, in the same growth trial, the expression of NaPi-IIb cotransporter was needed to be detected in the intestine, which transports inorganic P from lumen to blood when dietary $\mathrm{P}$ content is pretty low in lumen (in another manuscript) and probably would be affected if we chose $\mathrm{NaH}_{2} \mathrm{PO}_{4} \cdot \mathrm{H}_{2} \mathrm{O}$ or $\mathrm{KH}_{2} \mathrm{PO}_{4} \cdot \mathrm{H}_{2} \mathrm{O}$.

The purpose of this study was to investigate the effects of different dietary $\mathrm{P}$ levels on growth performance, body composition, and hepatic antioxidant property of juvenile yellow catfish.

\section{Materials and Methods}

2.1. Diet Preparation. Six experimental diets were formulated to contain graded levels of available $\mathrm{P}(0.33,0.56,0.81$,

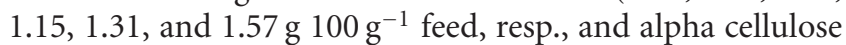

used as filler). Formulation and chemical composition of the diets are presented in Table $1 . \mathrm{P}$ content in each ingredient was as follows (as \% dry matter): casein 0.74 , blood meal 0.44 , gelatin 0.08 , squid meal 0.97 , and wheat flour 0.01 . Chromic (III) oxide $\left(\mathrm{Cr}_{2} \mathrm{O}_{3}\right)$ was added $(1.0 \%)$ to the diets as an inert digestion marker.

All the ingredients were finely ground to pass through 60 mesh sieve $(250 \mu \mathrm{m})$ and weighed. The dry ingredients were mixed one by one manually for at least $20 \mathrm{~min}$. Then fish oil and soy bean oil were added and mixed-in for another 20 min. Finally the mixture was transferred to a mixer and homogenized for about $20 \mathrm{~min}$. Distilled water was added to the mixture to achieve a proper pelleting consistency, and then the mixture was extruded through a $2.0 \mathrm{~mm}$ diameter die to form pellets. After that, diets were dried in an oven at $60^{\circ} \mathrm{C}$ until the moisture was reduced to less than $10 \%$, then stored in a freezer at $-20^{\circ} \mathrm{C}$ until use. A representative sample was taken for proximate analysis. The stability of $\mathrm{P}$ in diets was tested by measuring the total $\mathrm{P}$ content in the diets before and after immersed in water for $30 \mathrm{~min}$, and the result showed that the experimental diets held $97.35 \%$ total $\mathrm{P}$ after immersed in water for $30 \mathrm{~min}$.

2.2. Growth Trial. About 1400 yellow catfish larvae were obtained from Southlake hatchery based in Wuhan (Hubei, China) and then were stocked in 18 indoor fiberglass tanks (water volume, $395 \mathrm{~L}$ ) in aquaculture center of The College of Fisheries, Huazhong Agricultural University. Before starting the experiment, all the larvae were acclimatized to laboratory conditions for four weeks; for the first two weeks, the larvae were fed with Tubificidae and the next two weeks were fed with the basal diet (diet 1) (Table 1). Prior to the feeding trial, all fish were starved for $24 \mathrm{~h}$. Altogether 1080 fish with similar size $(3.09 \pm 0.03 \mathrm{~g})$ were distributed into 18 indoor fiberglass tanks $(395 \mathrm{~L})$ at a stocking density of 60 fish per tank. Fifty fish with similar size around $3 \mathrm{~g}$ were anaesthetized in MS 222 (Sigma) solution $\left(100 \mathrm{mg} \mathrm{L}^{-1}\right)$ and then kept at $-20^{\circ} \mathrm{C}$ as initial samples for proximate analysis. Each diet was fed for eight weeks (from August to October in 2010) to triplicate groups of fish. During the experiment, water flow was maintained constant at $1.5 \mathrm{~L} \mathrm{~min}^{-1}$, water temperature was $27 \pm 0.4^{\circ} \mathrm{C}$, dissolved oxygen was about $8 \mathrm{mg} \mathrm{L}^{-1}$, and $\mathrm{pH}$ was $7.84 \pm 0.03$. During the experiment, the diurnal cycle was 12-h light/12-h dark.

Every morning about one hour before feeding, about $25 \%$ of the water from each tank was drained and replaced with fresh water. Feed was distributed to fish at 08:00 and 16:00 to apparent satiation, and each feeding period lasted for about $2 \mathrm{~h}$. The fish were fed every $30 \mathrm{~min}$ and altogether 4 times for each feeding period. Since yellow catfish was active in feed intake, this feeding strategy was to ensure fish in each tank eating up almost all the feed in about $30 \mathrm{~min}$. Apparent satiation was assessed by the feeding behavior of yellow catfish: when we threw the feed into the tanks, fish were not interested in the feed and did not swim quickly to get the feed actively. Uneaten feed was collected after the fourth feeding during each feeding period and complete feces were collected by siphoning after $2 \mathrm{~h}$ of feeding from the second week. The uneaten feed was dried to constant 
TABLe 1: Formulation and chemical composition of the experimental diets $\left(\mathrm{g} \mathrm{kg}^{-1}\right.$ dry matter).

\begin{tabular}{|c|c|c|c|c|c|c|}
\hline \multirow{2}{*}{ Ingredients } & \multicolumn{6}{|c|}{ Diets } \\
\hline & 1 & 2 & 3 & 4 & 5 & 6 \\
\hline Casein & 350.0 & 350.0 & 350.0 & 350.0 & 350.0 & 350.0 \\
\hline Blood meal & 100.0 & 100.0 & 100.0 & 100.0 & 100.0 & 100.0 \\
\hline Gelatin & 20.0 & 20.0 & 20.0 & 20.0 & 20.0 & 20.0 \\
\hline Squid meal & 70.0 & 70.0 & 70.0 & 70.0 & 70.0 & 70.0 \\
\hline Wheat flour & 210.0 & 210.0 & 210.0 & 210.0 & 210.0 & 210.0 \\
\hline Fish oil & 60.0 & 60.0 & 60.0 & 60.0 & 60.0 & 60.0 \\
\hline Soy bean oil & 30.0 & 30.0 & 30.0 & 30.0 & 30.0 & 30.0 \\
\hline Vitamin premix ${ }^{1}$ & 5.0 & 5.0 & 5.0 & 5.0 & 5.0 & 5.0 \\
\hline Mineral premix $(\mathrm{P} \text { free })^{2}$ & 27.5 & 27.5 & 27.5 & 27.5 & 27.5 & 27.5 \\
\hline Vitamin C & 5.0 & 5.0 & 5.0 & 5.0 & 5.0 & 5.0 \\
\hline Choline chloride & 2.5 & 2.5 & 2.5 & 2.5 & 2.5 & 2.5 \\
\hline $\mathrm{Cr}_{2} \mathrm{O}_{3}$ & 10.0 & 10.0 & 10.0 & 10.0 & 10.0 & 10.0 \\
\hline $\mathrm{Ca}\left(\mathrm{H}_{2} \mathrm{PO}_{4}\right)_{2} \cdot \mathrm{H}_{2} \mathrm{O}$ & 0.0 & 12.0 & 24.0 & 36.0 & 48.0 & 60.0 \\
\hline$\alpha$-cellulose & 110.0 & 98.0 & 86.0 & 74.0 & 62.0 & 50.0 \\
\hline \multicolumn{7}{|c|}{ Chemical composition (per kg dry matter) } \\
\hline Moisture (g) & 83.9 & 98.6 & 78.3 & 71.0 & 92.5 & 99.6 \\
\hline Crude protein (g) & 455.9 & 452.9 & 447.5 & 446.1 & 457.5 & 444.1 \\
\hline Crude lipid (g) & 62.8 & 62.6 & 65.4 & 60.1 & 63.3 & 62.7 \\
\hline $\operatorname{Ash}(\mathrm{g})$ & 48.2 & 52.3 & 59.1 & 69.6 & 77.0 & 87.0 \\
\hline Total phosphorus (g) & 3.8 & 6.3 & 8.9 & 12.2 & 14.2 & 17.1 \\
\hline Available phosphorus (g) & 3.3 & 5.6 & 8.1 & 11.5 & 13.1 & 15.7 \\
\hline
\end{tabular}

${ }^{1}$ Vitamin Premix was bought from Fulong Feed Company in Wuhan (Hubei province, China) and contained the following vitamins ( $\mathrm{mg} \mathrm{kg}^{-1} \mathrm{feed}$ ): vitamin $\mathrm{K}_{3}, 20$; niacin, 250; riboflavin, 50; pyridoxine, 25; thiamin, 25; D-calcium pantothenate, 100; biotin, 1.5; foliacin, 10; vitamin $\mathrm{B}_{12}, 0.125$; ascorbic acid, 250; inositol, 750; (IU kg-1 feed): vitamin A, 17500; vitamin $\mathrm{D}_{3}, 2500$; vitamin E, 175.

${ }^{2}$ Mineral premix (P free) contained the following minerals (mg kg-1 feed): $\mathrm{NaCl}, 275 ; \mathrm{MgSO}_{4} \cdot 7 \mathrm{H}_{2} \mathrm{O}, 4125 ; \mathrm{Na}_{2} \mathrm{SO}_{4}, 6270 ; \mathrm{K}_{2} \mathrm{SO}_{4}, 5638 ; \mathrm{CaCl}_{2} \cdot 2 \mathrm{H}_{2} \mathrm{O}, 3218$; $\mathrm{FeSO}_{4}, 688$; Calcium lactate, $963 ; \mathrm{ZnSO}_{4} \cdot 7 \mathrm{H}_{2} \mathrm{O}, 97 ; \mathrm{MnSO}_{4} \cdot 4 \mathrm{H}_{2} \mathrm{O}, 45 ; \mathrm{CuSO}_{4} \cdot 5 \mathrm{H}_{2} \mathrm{O}, 8.53 ; \mathrm{CoSO}_{4}, 0.28 ; \mathrm{KI}, 0.83$.

weight at $60^{\circ} \mathrm{C}$ in an oven and weighed to determine daily feed consumption. Pooled feces of each tank were also dried at $60^{\circ} \mathrm{C}$. Mortality was checked daily. The cultured water was disinfected periodically by chlorine dioxide to prevent diseases.

2.3. Sample Collection and Analysis. At the end of the experiment, all fish were starved for $24 \mathrm{~h}$, counted, bulk weighed by tank for the calculation of survival rate and growth rate, and then returned to each tank. Ten fish were randomly selected from each tankanaesthetized in MS 222 (Sigma) $\left(200 \mathrm{mg} \mathrm{L}^{-1}\right)$ and then kept at $-20^{\circ} \mathrm{C}$ for whole body proximate composition and mineral analysis.

Five fish from each tank were selected randomly, anaesthetized (MS 222, $200 \mathrm{mg} \mathrm{L}^{-1}$ ), and then kept at $-20^{\circ} \mathrm{C}$ for vertebrae samples. Vertebrae were removed from fish after heating fish in a microwave oven for $120 \mathrm{~s}$, then lightly scrubbed and washed with distilled water to remove surrounding tissues and muscles, dried in an oven at $105^{\circ} \mathrm{C}$ for $6 \mathrm{~h}$, extracted with $20 \mathrm{~mL}$ chloroform and methanol (1:1, $\mathrm{v} / \mathrm{v})$ for $12 \mathrm{~h}$ to remove lipid, and then dried.

Three fish from each tank were selected randomly, anaesthetized (MS 222, $200 \mathrm{mg} \mathrm{L}^{-1}$ ) first, and then liver samples of these three fish from each tank were frozen immediately in liquid nitrogen and kept at $-80^{\circ} \mathrm{C}$ until use. Before measuring the activity of antioxidative enzymes, the pooled livers by tank were manually homogenized in a glass homogenizer with $0.7 \% \mathrm{NaCl}(\mathrm{w} / \mathrm{v})$ to $10 \%$ homogenate.

Chemical compositions of the dried whole fish, experimental diets, pretreated vertebrae and feces were examined using the following procedure: body ash content and vertebrae ash content by incinerating samples at $550^{\circ} \mathrm{C}$ for $18 \mathrm{~h}$ in a muffle furnace, then wet digested with $\mathrm{HCl}$ and $\mathrm{HNO}_{3}$ subsequently for the analysis of $\mathrm{P}$ content by the molybdovanadate method [21]; crude protein $(\mathrm{N} \times 6.25)$ by the Kjeldahl method [21]; crude lipid by extraction with petroleum ether for $12 \mathrm{~h}$ in a Soxhlet extractor [21]; moisture content by drying to constant weight at $105^{\circ} \mathrm{C}$ for $6 \mathrm{~h}$ [21] . Body calcium and vertebrae calcium contents were analyzed by atomic absorption spectrophotometer (Varian AA240FS Fast Sequential AA Spectrometer, USA). Chromium content of experimental diets and feces was determined using the procedure of Bolin et al. [22].

Activities of liver superoxide dismutase (SOD), catalase (CAT), and glutathione peroxidase (GSH-Px) and content of malonaldehyde (MDA) were all analyzed spectrophotometrically using diagnostic reagent kits (Nanjing Jiancheng Bioengineering Institute, China). 
2.4. Calculation and Statistical Analysis. Growth parameters were calculated according to the following equations:

Specific growth rate (SGR \% day ${ }^{-1}$ )

$$
=100 \times \frac{[\operatorname{Ln}(\text { final weight })-\operatorname{Ln}(\text { initial weight })]}{\text { duration }(\text { days })},
$$

Feed efficiency $\left(\right.$ FE \%) $=100 \times \frac{\text { wet weight gain }}{\text { dry feed intake }}$,

Feeding rate (FR \% BW day $\left.{ }^{-1}\right)$

$$
=100 \times \frac{\text { dry feed intake }}{[\text { days } \times(\text { FBW }+ \text { IBW }) / 2]},
$$

Survival $(\%)=100 \times \frac{\text { final numbers of fish }}{\text { initial numbers of fish }}$,

Protein efficiency ratio $\left(\right.$ PER \%) $=\frac{\text { weight gain }}{\text { crude protein intake }}$,

Protein retention efficiency (PRE \%)

$$
=100 \times\left(\frac{\text { protein retained in fish body }}{\text { protein intake }}\right),
$$

Apparent digestibility coefficient of dry matter (ADCd \%)

$$
=100 \times\left[1-\left(\frac{\mathrm{Cr}_{2} \mathrm{O}_{3} \text { in the diet }}{\mathrm{Cr}_{2} \mathrm{O}_{3} \text { in the feces }}\right)\right],
$$

Apparent digestibility coefficient of protein (ADCp \%)

$$
\begin{aligned}
=100 \times & {\left[1-\left(\frac{\mathrm{Cr}_{2} \mathrm{O}_{3} \text { in the diet }}{\mathrm{Cr}_{2} \mathrm{O}_{3} \text { in the feces }}\right)\right.} \\
& \left.\times\left(\frac{\text { crude protein in feces }}{\text { crude protein in the diet }}\right)\right],
\end{aligned}
$$

Apparent digestibility coefficient of P (ADCph \%)

$$
=100 \times\left[1-\left(\frac{\mathrm{Cr}_{2} \mathrm{O}_{3} \text { in the diet }}{\mathrm{Cr}_{2} \mathrm{O}_{3} \text { in the feces }}\right) \times\left(\frac{\mathrm{P} \text { in feces }}{\mathrm{P} \text { in the diet }}\right)\right],
$$

Efficiency of phosphorus (P) utilization (\%)

$$
\begin{aligned}
=100 \times & {\left[\frac{(\text { final phosphorus fish content })}{\text { phosphorus intake }}\right.} \\
& \left.-\frac{(\text { initial phosphorus fish content })}{\text { phosphorus intake }}\right],
\end{aligned}
$$

Available P content of the diets

$=$ total $\mathrm{P}$ content

$\times$ apparent digestibility coefficient of $\mathrm{P}(\mathrm{ADCph})$ of the diets.

Since we wanted to compare the levels of the dietary available $\mathrm{P}$ to see if change in the levels leads to a significant change in the response, we chose the model of one-way analysis of variance (ANOVA) to analyze all the relative responses. When differences among levels were identified, Duncan's multiple-range tests were used to determine the significant differences among different level treatment means of dietary available $\mathrm{P}$ at $\alpha=0.05$ (Statistica 8.0 software, StatSoft Inc, Tulsa, Oklahoma). The data were presented as means $\pm \mathrm{SE}$.

To estimate maximum vertebrae $\mathrm{P}$, we fitted a quadratic regression line to vertebrae $P$ as a function of dietary available P level using SPSS 16.0 (SPSS Inc, Chicago, Ill, USA).

\section{Results}

3.1. Apparent Digestibility, Efficiency of $P$ Utilization, and Feces $P$. Apparent digestibility coefficient of $\mathrm{P}$ (ADCph), dry matter and protein digestibility was shown in Table 2. There was no significant difference in dry matter and protein digestibility (ADCd and $\mathrm{ADCp})(P>0.05)$ among all treatments. Apparent digestibility of $\mathrm{P}$ (ADCph) significantly increased with increasing dietary available $\mathrm{P}$ up to the $0.81 \%$ level $(P<0.05)$ and then plateaued with further increases in dietary available $\mathrm{P}$. Efficiency of $\mathrm{P}$ utilization decreased $(P<0.05)$ and feces $\mathrm{P}$ content increased with the increase of the dietary P level (Table 2).

3.2. Growth Performance. Effects of dietary available P on growth performance were shown in Table 3. The final body weight (FBW), specific growth rate (SGR), and feeding rate (FR) were all significantly improved by dietary available $\mathrm{P}$ up to $0.81 \%(P<0.05)$ and then significantly decreased compared to the $0.81 \%$ dietary group $(P<0.05)$. The protein efficiency ratio (PER) of the $0.81 \%$ and $1.57 \%$ groups was significantly higher than that of the other groups $(P<0.05)$. However, dietary available $\mathrm{P}$ had no significant effects on feed efficiency (FE), protein retention efficiency (PRE), and survival rate.

3.3. Body Composition. Dietary available P level significantly affected yellow catfish whole body crude lipid, ash, Ca, vertebrae $\mathrm{P}, \mathrm{Ca}$, and ash content $(P<0.05)$ (Table 4$)$. With the increase of dietary available $\mathrm{P}$, body crude lipid content significantly decreased $(P<0.05)$. Body ash, vertebrae ash, and vertebrae $\mathrm{P}$ content increased until available $\mathrm{P}$ reached $1.31 \%(P<0.05)$, then decreased. Quadratic regression analysis showed that the maximum vertebrae $P$ accumulation occurred at a dietary available P of $1.21 \%$ (Figure 1).

3.4. Antioxidant Property. Dietary available $\mathrm{P}$ content significantly affected hepatic SOD and CAT activity and MDA content $(P<0.05)$ (Table 5). Fish in the highest dietary available $\mathrm{P}$ content $(1.57 \%)$ group had higher SOD, CAT activity, and MDA content than all the other groups $(P<0.05)$. There was no significant difference in GSH-Px activity among all the groups $(P>0.05)$.

\section{Discussion}

In the present study, we found the efficiency of $\mathrm{P}$ utilization increased with decreasing dietary available P. There are two patterns for $\mathrm{P}$ absorption in animals. When the concentration of inorganic $\mathrm{P}$ is high in the lumen, passive 
TABle 2: Effects of dietary available P level on apparent digestibility coefficient (ADC), P utilization efficiency, and feces P content in yellow catfish fed experimental diets for eight weeks (Mean $\pm \mathrm{SE}, n=3$ ).

\begin{tabular}{lcccccc}
\hline Available P in diet (\%) & 0.33 & 0.56 & 0.81 & 1.15 & 1.31 \\
\hline Dry matter (ADCd, \%) & $87.21 \pm 2.94$ & $83.21 \pm 2.58$ & $87.17 \pm 1.37$ & $89.29 \pm 1.29$ & $88.08 \pm 2.69$ & $88.21 \pm 0.04$ \\
Protein (ADCp, \%) & $98.22 \pm 0.41$ & $96.89 \pm 0.43$ & $97.48 \pm 0.13$ & $97.80 \pm 0.36$ & $97.38 \pm 0.65$ & $97.47 \pm 0.06$ \\
P (ADCph, \%) & $87.01 \pm 3.40^{\mathrm{b}}$ & $89.43 \pm 1.26^{\mathrm{bc}}$ & $90.47 \pm 0.67^{\mathrm{abc}}$ & $94.18 \pm 0.50^{\mathrm{a}}$ & $92.57 \pm 1.59^{\mathrm{ac}}$ & $92.06 \pm 0.20^{\mathrm{ac}}$ \\
Efficiency of P utilization (\%) & $77.46 \pm 7.45^{\mathrm{a}}$ & $57.99 \pm 5.37^{\mathrm{ab}}$ & $54.45 \pm 3.81^{\mathrm{b}}$ & $46.38 \pm 7.43^{\mathrm{b}}$ & $37.51 \pm 3.41^{\mathrm{b}}$ & $45.18 \pm 10.30^{\mathrm{b}}$ \\
Feces P (g kg-1 dry matter) & $0.38 \pm 0.01^{\mathrm{d}}$ & $0.40 \pm 0.02^{\mathrm{d}}$ & $0.67 \pm 0.03^{\mathrm{c}}$ & $0.67 \pm 0.03^{\mathrm{c}}$ & $0.89 \pm 0.01^{\mathrm{b}}$ & $1.15 \pm 0.03^{\mathrm{a}}$ \\
\hline
\end{tabular}

Note: values with different letters within the same row are significantly different $(P<0.05)$.

TABLE 3: The growth performance of yellow catfish under different dietary treatments for eight weeks (Mean \pm SE, $n=3$ ).

\begin{tabular}{|c|c|c|c|c|c|c|}
\hline Available $\mathrm{P}$ in $\operatorname{diet}(\%)$ & 0.33 & 0.56 & 0.81 & 1.15 & 1.31 & 1.57 \\
\hline IBW (g) & $3.02 \pm 0.05$ & $3.10 \pm 0.03$ & $3.03 \pm 0.09$ & $3.00 \pm 0.07$ & $3.14 \pm 0.06$ & $3.23 \pm 0.01$ \\
\hline FBW (g) & $6.08 \pm 0.09^{b c}$ & $6.44 \pm 0.08^{\mathrm{b}}$ & $7.51 \pm 0.36^{\mathrm{a}}$ & $5.45 \pm 0.23^{\mathrm{c}}$ & $6.19 \pm 0.36^{\mathrm{bc}}$ & $6.58 \pm 0.21^{\mathrm{b}}$ \\
\hline SGR $\left(\%\right.$ day $\left.^{-1}\right)$ & $1.25 \pm 0.01^{\mathrm{bc}}$ & $1.31 \pm 0.02^{\mathrm{b}}$ & $1.62 \pm 1.10^{\mathrm{a}}$ & $1.06 \pm 0.04^{\mathrm{c}}$ & $1.21 \pm 0.08^{\mathrm{bc}}$ & $1.27 \pm 0.06^{\mathrm{b}}$ \\
\hline FR $\left(\%\right.$ BW day $\left.{ }^{-1}\right)$ & $1.74 \pm 0.08^{\mathrm{b}}$ & $1.70 \pm 0.02^{\mathrm{b}}$ & $1.93 \pm 0.02^{\mathrm{a}}$ & $1.46 \pm 0.06^{\mathrm{c}}$ & $1.57 \pm 0.04^{\mathrm{c}}$ & $1.54 \pm 0.01^{\mathrm{c}}$ \\
\hline $\mathrm{FE}(\%)$ & $64.40 \pm 1.81$ & $68.57 \pm 1.07$ & $73.04 \pm 3.69$ & $64.92 \pm 4.05$ & $69.45 \pm 2.59$ & $76.31 \pm 3.83$ \\
\hline PER (\%) & $1.36 \pm 0.04^{\mathrm{b}}$ & $1.45 \pm 0.04^{\mathrm{b}}$ & $1.56 \pm 0.11^{\mathrm{ab}}$ & $1.35 \pm 0.10^{\mathrm{b}}$ & $1.45 \pm 0.04^{\mathrm{b}}$ & $1.70 \pm 0.09^{\mathrm{a}}$ \\
\hline PRE (\%) & $17.63 \pm 0.94$ & $19.26 \pm 3.29$ & $21.33 \pm 1.72$ & $21.75 \pm 1.02$ & $19.91 \pm 1.96$ & $21.59 \pm 2.61$ \\
\hline Survival rate (\%) & $92.22 \pm 0.56$ & $91.67 \pm 1.67$ & $89.44 \pm 2.00$ & $90.56 \pm 2.00$ & $92.78 \pm 2.42$ & $96.11 \pm 0.56$ \\
\hline
\end{tabular}

Note: IBW: initial body weight; FBW: final body weight; SGR: specific growth rate; FR: feeding rate; FE: feed efficiency; PER: protein efficiency ratio; PRE: protein retention efficiency.

Values with different letters within the same row are significantly different $(P<0.05)$.

TABLe 4: Effects of dietary available P level on body composition of yellow catfish for eight weeks (Mean \pm SE, $n=3$ ).

\begin{tabular}{|c|c|c|c|c|c|c|c|}
\hline Available $\mathrm{P}$ in $\operatorname{diet}(\%)$ & Initial & 0.33 & 0.56 & 0.81 & 1.15 & 1.31 & 1.57 \\
\hline \multicolumn{8}{|c|}{ Whole body (\% of wet weight) } \\
\hline Moisture & $76.95 \pm 0.60$ & $74.20 \pm 1.62$ & $75.73 \pm 1.48$ & $74.26 \pm 0.78$ & $74.44 \pm 0.99$ & $75.07 \pm 1.00$ & $76.89 \pm 1.35$ \\
\hline Crude protein & $12.79 \pm 0.40$ & $12.93 \pm 0.50$ & $13.01 \pm 1.00$ & $13.28 \pm 0.23$ & $14.10 \pm 0.65$ & $13.24 \pm 0.68$ & $12.75 \pm 0.67$ \\
\hline Crude lipid & $3.83 \pm 0.21^{\mathrm{c}}$ & $6.49 \pm 0.70^{\mathrm{a}}$ & $4.57 \pm 0.60^{\mathrm{bc}}$ & $5.47 \pm 0.61^{\mathrm{ab}}$ & $4.43 \pm 0.26^{\mathrm{bc}}$ & $4.44 \pm 0.25^{\mathrm{bc}}$ & $3.62 \pm 0.43^{c}$ \\
\hline Ash & $3.36 \pm 0.13^{\text {bd }}$ & $3.27 \pm 0.16^{\mathrm{d}}$ & $3.63 \pm 0.12^{\mathrm{bd}}$ & $3.97 \pm 0.23^{\mathrm{abc}}$ & $4.31 \pm 0.19^{\mathrm{a}}$ & $4.46 \pm 0.34^{\mathrm{a}}$ & $4.14 \pm 0.17^{\mathrm{ab}}$ \\
\hline Body P & $0.64 \pm 0.07$ & $0.63 \pm 0.02$ & $0.66 \pm 0.02$ & $0.71 \pm 0.04$ & $0.81 \pm 0.05$ & $0.80 \pm 0.04$ & $0.81 \pm 0.09$ \\
\hline Body Ca & $0.26 \pm 0.02^{c}$ & $0.30 \pm 0.03^{b c}$ & $0.33 \pm 0.01^{\mathrm{ab}}$ & $0.37 \pm 0.03^{\mathrm{a}}$ & $0.38 \pm 0.01^{\mathrm{a}}$ & $0.38 \pm 0.01^{\mathrm{a}}$ & $0.38 \pm 0.01^{\mathrm{a}}$ \\
\hline \multicolumn{8}{|c|}{ Vertebrae (P and $\mathrm{Ca}, \mathrm{g} \mathrm{kg}^{-1}$; ash, \% of dry matter) } \\
\hline $\mathrm{P}$ & 72.00 & $59.58 \pm 2.92^{\mathrm{c}}$ & $64.66 \pm 0.30^{\mathrm{bc}}$ & $66.99 \pm 1.74^{\mathrm{ab}}$ & $69.28 \pm 2.07^{\mathrm{ab}}$ & $72.26 \pm 1.72^{\mathrm{a}}$ & $67.46 \pm 0.86^{\mathrm{ab}}$ \\
\hline $\mathrm{Ca}$ & 38.78 & $28.51 \pm 1.19^{\mathrm{b}}$ & $34.09 \pm 0.93^{\mathrm{a}}$ & $33.67 \pm 2.13^{\mathrm{a}}$ & $34.15 \pm 0.79^{\mathrm{a}}$ & $35.67 \pm 2.36^{\mathrm{a}}$ & $35.84 \pm 0.96^{\mathrm{a}}$ \\
\hline Ash & 38.35 & $28.49 \pm 1.10^{c}$ & $34.63 \pm 0.21^{\mathrm{b}}$ & $35.60 \pm 0.98^{\mathrm{b}}$ & $37.11 \pm 0.86^{\mathrm{ab}}$ & $39.08 \pm 0.68^{\mathrm{a}}$ & $36.58 \pm 0.48^{\mathrm{ab}}$ \\
\hline
\end{tabular}

Note: values with different letters within the same row are significantly different $(P<0.05)$.

TABLE 5: Effects of dietary available P level on hepatic biochemical indicators of yellow catfish for eight weeks (Mean \pm SE, $n=3$ ).

\begin{tabular}{|c|c|c|c|c|c|c|}
\hline$\% \mathrm{P}$ in diet & 0.33 & 0.56 & 0.81 & 1.15 & 1.31 & 1.57 \\
\hline SOD (U mgpro $\left.{ }^{-1}\right)$ & $33.94 \pm 2.27^{c}$ & $37.09 \pm 4.07^{\mathrm{bc}}$ & $46.19 \pm 5.37^{\mathrm{ab}}$ & $37.74 \pm 0.69^{b c}$ & $39.98 \pm 3.47^{\mathrm{bc}}$ & $56.46 \pm 4.92^{\mathrm{a}}$ \\
\hline CAT ( U mgpro ${ }^{-1}$ ) & $4.87 \pm 0.54^{\mathrm{b}}$ & $4.75 \pm 0.44^{\mathrm{b}}$ & $5.68 \pm 0.42^{\mathrm{ab}}$ & $4.59 \pm 0.27^{\mathrm{b}}$ & $4.79 \pm 0.32^{\mathrm{b}}$ & $6.97 \pm 0.63^{\mathrm{a}}$ \\
\hline MDA (nmol mgpro-1) & $0.48 \pm 0.06^{\mathrm{b}}$ & $0.50 \pm 0.04^{\mathrm{b}}$ & $0.77 \pm 0.06^{\mathrm{a}}$ & $0.45 \pm 0.03^{b}$ & $0.54 \pm 0.07^{\mathrm{b}}$ & $0.89 \pm 0.11^{\mathrm{a}}$ \\
\hline GSH-Px (U) & $2.02 \pm 0.44$ & $2.66 \pm 0.61$ & $1.89 \pm 0.50$ & $1.47 \pm 0.58$ & $2.18 \pm 0.33$ & $2.43 \pm 0.56$ \\
\hline
\end{tabular}

Note: values in the same row with different letters are significantly different $(P<0.05)$.

SOD: superoxide dismutase; CAT: catalase; GSH-Px: glutathione peroxidase; MDA: malonaldehyde. 


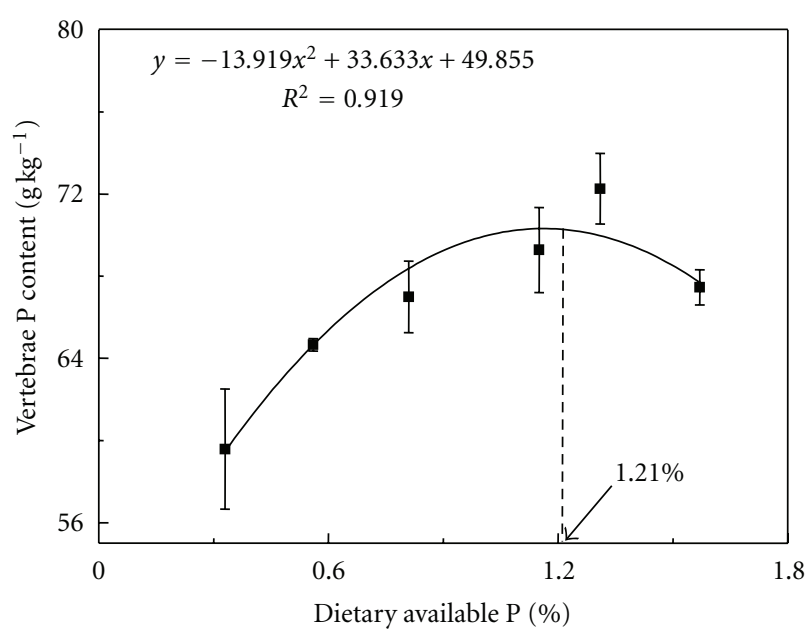

Figure 1: Effect of dietary available P level on vertebrae P content of juvenile yellow catfish. The predicted maximum level occurred at dietary available $\mathrm{P}$ equal to $1.21 \%$, based on quadratic regression analysis.

transportation of $\mathrm{P}$ is predominant; when the concentration of $\mathrm{P}$ is low, active transportation of $\mathrm{P}$ via $\mathrm{NaPi}$ cotransporter is predominant [23]. The present study showed that lower dietary $\mathrm{P}$ level led to higher $\mathrm{P}$ utilization; similar results were observed in rainbow trout [24] and black sea bream [25]. However, these authors didn't give any explanation on this observed phenomenon. We inferred that low dietary $\mathrm{P}$ content stimulated the active transportation of $\mathrm{P}$ in the intestine and thus increased $\mathrm{P}$ absorption.

Effects of dietary $\mathrm{P}$ level on growth performance were reported in many fish species. Improved growth was seen in common carp [26], juvenile haddock [2], juvenile silver perch [27], and juvenile black sea bream [26]. However, other studies reported that dietary $\mathrm{P}$ level did not change the growth of sea bass [28] and Atlantic salmon [29]. Animal growth depends on several factors, including age, stage of development, diet composition, duration of experiment, health, and rearing condition. Young animals were more sensitive to nutrient deficiency than those at a later stage of development [2]. In the current study, juvenile yellow catfish (average initial body weight was about $3 \mathrm{~g}$ ) were sensitive to dietary $\mathrm{P}$ content and showed different growth performance under different dietary $\mathrm{P}$ treatments. However, the improved growth performance was only observed until the dietary available $\mathrm{P}$ level reached $0.81 \%$, indicating that juvenile yellow catfish needed about $0.8 \%$ dietary available $\mathrm{P}$ to obtain maximum growth. There were several reports about catfish dietary available $P$ requirements based on channel catfish (Ictalurus punctatus). Andrews et al. [18] reported that the $\mathrm{P}$ requirement of catfish is 0.8 percent of available $\mathrm{P}$ in practical-type diets. However, Lovell [19] and Wilson et al. [20] reevaluated the $\mathrm{P}$ requirement using chemically defined diets and estimated it to be approximately 0.42 percent available P. NRC [1] recommended the appropriate dietary available $\mathrm{P}$ to be 0.45 percent for channel catfish.
However, in the present study, this small omnivorous fish gained highest growth at $0.81 \%$ dietary available $\mathrm{P}$. The difference between yellow catfish and channel catfish was probably due to the species specific, different growth rate, and ingredients content of the diets or the culture system.

Dietary P level had no effects on fish whole body moisture and crude protein content in the present study, which was similar to findings in red sea bream [30] and European sea bass [31]. However, crude lipid content decreased with increasing level of dietary $\mathrm{P}$ in our experiment. An inverse relationship between whole body crude lipid content and dietary $\mathrm{P}$ was also reported in channel catfish [32], red sea bream [30, 33], common carp [34], juvenile haddock [2], Japanese sea bass [35], large yellow croaker [36], and juvenile black sea bream [25]. Since P plays an important role in energy metabolism and lipid beta oxidation, $\mathrm{P}$ deficiency will cause cellular hypoxia and thus produce more lipid. The reduction in the lipid content of the fish fed higher levels of $\mathrm{P}$ may be due to enhancement of $\mathrm{P}$ oxidation of fatty acids, increase in glycogenesis or some type of repartitioning effect, resulting in increased deposition of protein and reduced deposition of lipid [32].

The whole-body or vertebrae ash and P levels had been commonly used as indicators of dietary $\mathrm{P}$ status in fish nutrition studies $[4,25,36-38]$. Signs of $\mathrm{P}$ deficiency are poor bone mineralization and bad growth performance. Dietary available P levels greatly affected the ash, calcium, and $\mathrm{P}$ contents both of the whole body and vertebrae of carp [39]. In our study, whole-body ash, vertebrae, ash and vertebrae $\mathrm{P}$ content of juvenile yellow catfish increased until dietary available $\mathrm{P}$ level reached $1.31 \%$ and then decreased at the $1.57 \%$ dietary available P level. Quadratic analysis based on vertebrae $\mathrm{P}$ contents indicated maximum vertebrae $\mathrm{P}$ at a dietary available $\mathrm{P}$ of $1.21 \%$, higher than the requirement of $0.81 \%$ dietary available $\mathrm{P}$ for maximum growth. Similar findings were reported in large yellow croaker [36] and black sea bream [25]. The minimum available $\mathrm{P}$ requirement for maximum growth of large yellow croaker was $0.70 \%$; however, based on the $\mathrm{P}$ content in either vertebrae or whole body, the requirements were $0.89 \%$ and $0.91 \%$, respectively. In black sea bream, maximum weight gain was obtained at dietary available $\mathrm{P}$ concentration of $0.55 \%$; however, quadratic analysis based on $\mathrm{P}$ content in vertebrae indicated that the requirement was $0.87 \%$. The dietary $\mathrm{P}$ requirement for bone mineralization was usually higher than that for maximum growth $[32,40]$. Differences among empirically established $\mathrm{P}$ requirements may be due in part to differences in the choice of response variable used [41]. The requirement must depend on what is considered a physiologically, economically, or environmentally important trait [32]. Thus, in the present study, if growth rate is used as a marker the requirement is $0.8 \%$, but if maximum vertebrae $\mathrm{P}$ content is applied the requirement is $1.2 \%$. If the dietary available $\mathrm{P}$ level is higher than $0.8 \%$ the growth is reduced. Considering the economic cost and environmental cost, dietary available $\mathrm{P}$ level of $0.8 \%$ is recommended for young yellow catfish.

Only a few preliminary researches have been reported about the roles of minerals in the antioxidant system of 
aquatic animals, including selenium [42], iron [43], and zinc [44], no research concerns the role of phosphorus in antioxidant defense systems in fish. Since P is important in energy metabolism and lipid beta oxidation, lipid peroxidation is supposed to be susceptible to dietary P level. In order to elaborate the basic oxidative functional responses of yellow catfish under different dietary $\mathrm{P}$ treatments so to determine whether they could be used as indicators of the stimulatory activity of dietary P, we measured hepatic SOD, CAT, and GPx activities and the content of MDA. We found hepatic SOD, CAT, and MDA contents except GPx activities were significantly affected by dietary available P level. Unlike in plant, no antioxidant responses were observed in low $\mathrm{P}$ groups $(0.33 \%$ and $0.56 \%)$ compared to high $\mathrm{P}$ groups $(1.57 \%)$.

The effect of oral $\mathrm{P}$ exposure was reported in the form of white phosphorus [45]. $\mathrm{LD}_{50}$ values of $4.82 \mathrm{mg} \mathrm{kg}^{-1}$ and $4.85 \mathrm{mg} \mathrm{kg}^{-1}$ were reported for female and male mice, respectively [46]. Fish fed with the highest dietary available P (1.57\%) had the highest hepatic SOD and CAT activities and highest MDA content. The SOD in fish is known to be induced in those tissues that are suffering from oxidative stress [47]. Ou et al. [48] claimed that the induction of these antioxidant enzymes is an important protective mechanism to minimize cell oxidative damage in unfavorable environments. In our study, high-level dietary $\mathrm{P}$ induced the antioxidative responses in juvenile yellow catfish. It is possible that the fish in this study were under an oxidative stress at the high levels of dietary available $\mathrm{P}$ which no longer served as a required nutrient but tended to be a stressor. Since SOD and CAT play the major role in the process of eliminating the free radicals [12], hepatic SOD and CAT were upregulated in juvenile yellow catfish in order to reduce free radicals produced by high dietary P. However, upregulated levels of SOD and CAT were not enough to eliminate the free radicals in fish fed $1.57 \%$ dietary available $\mathrm{P}$, which led to the accumulation of the final product of lipid peroxidation, and finally the damage of cell membrane could not be restored in this group of fish.

\section{Conclusions}

This was the first study to show that dietary available $\mathrm{P}$ level affected hepatic antioxidant responses in fish. The current study indicated that the decrease of dietary available $\mathrm{P}$ increased the efficiency of $\mathrm{P}$ utilization and the body lipid content. However, vertebrae P also decreased, which could affect the bone mineralization of juvenile yellow catfish. Juvenile yellow catfish were subjected to oxidant damage and could not be reduced or eradicated by their own antioxidant defense system under the condition of high dietary $\mathrm{P}$ content. Therefore, as an essential nutrient for growth, bone mineralization, and maintaining the antioxidant property of this species, it is very important to optimize the dietary $\mathrm{P}$ content. In order to achieve the maximum growth rate, the optimal dietary available $\mathrm{P}$ of juvenile yellow catfish were estimated to be $0.81 \%$. Based on maximum vertebrae $\mathrm{P}$ content, the optimal dietary available $\mathrm{P}$ of juvenile yellow catfish were estimated to be $1.21 \%$.

\section{Acknowledgments}

This research was funded by the National Natural Science Foundation of China (Project no. 4004-094102) and the State Key Laboratory of Freshwater Ecology and Biotechnology (Project no. 2010FB11). The authors also thanked Dr. Min Xue from Chinese Academy of Agricultural Sciences for the help in feed formulation and Xuewen Lei, Chaofan Wang, and Qiao Liu for their great help during feeding trial and sample analysis.

\section{References}

[1] NRC, Nutrient Requirements of Fish and Shrimp, The National Academies Press, Washington, DC, USA, 2011.

[2] P. K. Roy and S. P. Lall, "Dietary phosphorus requirement of juvenile haddock (Melanogrammus aeglefinus L.)," Aquaculture, vol. 221, no. 1-4, pp. 451-468, 2003.

[3] R. M. Coloso, S. P. Basantes, K. King et al., "Effect of dietary phosphorus and vitamin D3 on phosphorus levels in effluent from the experimental culture of rainbow trout (Oncorhynchus mykiss)," Aquaculture, vol. 202, no. 1-2, pp. 145-161, 2001.

[4] R. W. Hardy, W.T. Fairgrieve, and T. M. Scott, "Periodic feeding of low-phosphorus diet and phosphorus retention in rainbow trout Oncorhynchus mykiss," in Fish Nutrition Practice, S. J. Kauchik and P. Luquet, Eds., no. 61, pp. 403-412, Les Colloques, INRA, Paris, France, 1993.

[5] R. K. Tewari, P. Kumar, N. Tewari, S. Srivastava, and P. N. Sharma, "Macronutrient deficiencies and differential antioxidant responses-influence on the activity and expression of superoxide dismutase in maize," Plant Science, vol. 166, no. 3, pp. 687-694, 2004.

[6] I. Juszczuk, M. Malusa, and A. Rychter, "Phosphate deficiency induced oxidative stress in bean (Phaseolus vulgaris L.)," in Development in Plant and Soil Sciences, W. J. Horst, M.K. Schenk, A. Bürkert et al., Eds., vol. 92 of Plant NutritionFood Security and Sustainability of Agro-Ecosystems, pp. 148149, Kluver Academic Publishers, Dordecht, The Netherlands, 2002.

[7] O. T. Zribi, C. Abdelly, and A. Debez, "Interactive effects of salinity and phosphorus availability on growth, water relations, nutritional status and photosynthetic activity of barley (Hordeum vulgare L.)," Plant Biology, vol. 13, no. 6, pp. 872-880, 2011.

[8] Y. Yao, H. Sun, F. Xu, X. Zhang, and S. Liu, "Comparative proteome analysis of metabolic changes by low phosphorus stress in two Brassica napus genotypes," Planta, vol. 233, no. 3, pp. 523-537, 2011.

[9] R. G. Alscher, J. L. Donahue, and C. L. Cramer, "Reactive oxygen species and antioxidants: relationships in green cells," Physiologia Plantarum, vol. 100, no. 2, pp. 224-233, 1997.

[10] C. H. Foyer, H. Lopez-Delgado, J. F. Dat, and I. M. Scott, "Hydrogen peroxide- and glutathione-associated mechanisms of acclimatory stress tolerance and signalling," Physiologia Plantarum, vol. 100, no. 2, pp. 241-254, 1997.

[11] G. Noctor and C. H. Foyer, "Ascorbate and glutathione: keeping active oxygen under control," Annual Review of Plant Biology, vol. 49, pp. 249-279, 1998.

[12] M. Valko, D. Leibfritz, J. Moncol, M. T. D. Cronin, M. Mazur, and J. Telser, "Free radicals and antioxidants in normal physiological functions and human disease," International Journal of Biochemistry and Cell Biology, vol. 39, no. 1, pp. 44-84, 2007. 
[13] I. Ahmad, T. Hamid, M. Fatima et al., "Induction of hepatic antioxidants in freshwater catfish (Channa punctatus Bloch) is a biomarker of paper mill effluent exposure," Biochimica et Biophysica Acta, vol. 1523, no. 1, pp. 37-48, 2000.

[14] B. Chance, J. S. Leigh, and J. Kent, "Multiple controls of oxidative metabolism in living tissues as studied by phosphorus magnetic resonance," Proceedings of the National Academy of Sciences of the United States of America, vol. 83, no. 24, pp. 9458-9462, 1986.

[15] S. D. Walwadkar, A. N. Suryakar, R. V. Katkam, K. M. Kumbar, and R. D. Ankush, "Oxidative stress and calcium-phosphorus levels in rheumatoid arthritis," Indian Journal of Clinical Biochemistry, vol. 21, no. 2, pp. 134-137, 2006.

[16] China Fishery Statistical Yearbook, Fishery Bureau of Ministry of Agriculture, China Agriculture Press, 2010.

[17] H. J. Wang, X. M. Liang, P. H. Jiang, J. Wang, S. K. Wu, and H. Z. Wang, "TN : TTP ratio and planktivorous fish do not affect nutrient-chlorophyll relationships in shallow lakes," Freshwater Biology, vol. 53, no. 5, pp. 935-944, 2008.

[18] J. W. Andrews, T. Murai, and C. Campbell, "Effects of dietary calcium and phosphorus on growth, food conversion, bone ash and hematocrit levels of catfish," Journal of Nutrition, vol. 103, no. 5, pp. 766-771, 1973.

[19] R. T. Lovell, "Dietary phosphorus requirement of channel catfish (Ictalurus punctatus)," Transactions of the American Fisheries Society, vol. 107, no. 4, pp. 617-621, 1978.

[20] R. P. Wilson, E. H. Robinson, D. M. Gatlin, and W. E. Poe, "Dietary phosphorus requirement of channel catfish," Journal of Nutrition, vol. 112, no. 6, pp. 1197-1202, 1982.

[21] AOAC, Official Methods of Analysis, Association of Official Analytical Chemists, Washington, DC, USA, 16th edition, 1998.

[22] D. W. Bolin, R. P. King, and E. W. Klosterman, "A simplified method for the determination of chromic oxide $\left(\mathrm{Cr}_{2} \mathrm{O}_{3}\right)$ when used as an index substance," Science, vol. 116, no. 3023, pp. 634-635, 1952.

[23] S. H. Sugiura and R. P. Ferraris, "Contributions of different NaPi cotransporter isoforms to dietary regulation of $\mathrm{P}$ transport in the pyloric caeca and intestine of rainbow trout," Journal of Experimental Biology, vol. 207, no. 12, pp. 20552064, 2004.

[24] E. M. Avila, H. Tu, S. Basantes, and R. P. Ferraris, "Dietary phosphorus regulates intestinal transport and plasma concentrations of phosphate in rainbow trout," Journal of Comparative Physiology. B, vol. 170, no. 3, pp. 201-209, 2000.

[25] Q. Shao, J. Ma, Z. Xu, W. Hu, J. Xu, and S. Xie, "Dietary phosphorus requirement of juvenile black seabream, Sparus macrocephalus," Aquaculture, vol. 277, no. 1-2, pp. 92-100, 2008.

[26] B. Hepher and S. Sandbank, "The effect of phosphorus supplementation to common carp diets on fish growth," Aquaculture, vol. 36, no. 4, pp. 323-332, 1984.

[27] S. D. Yang, T. S. Lin, F. G. Liu, and C. H. Liou, "Influence of dietary phosphorus levels on growth, metabolic response and body composition of juvenile silver perch (Bidyanus bidyanus)," Aquaculture, vol. 253, no. 1-4, pp. 592-601, 2006.

[28] M. Boonyaratpalin, "Effects of ash and inorganic phosphorus in diets on growth and mineral composition of seabass Lates calcarifer (Bloch)," Aquaculture Research, vol. 32, supplement 1, pp. 53-59, 2001.

[29] J. Vielma and S. P. Lall, "Control of phosphorus homeostasis of Atlantic salmon (Salmo salar) in fresh water," Fish Physiology and Biochemistry, vol. 19, no. 1, pp. 83-93, 1998.
[30] S. Sakamoto and Y. Yone, "Effects of dietary phosphorus level on chemical composition of red sea bream," Bulletin of the Japanese Society of Scientific Fisheries, vol. 44, pp. 227-229, 1978.

[31] A. Oliva-Teles and A. Pimentel-Rodrigues, "Phosphorus requirement of European sea bass (Dicentrarchus labrax L.) juveniles," Aquaculture Research, vol. 35, no. 7, pp. 636-642, 2004.

[32] J. C. Eya and R. T. Lovell, "Available phosphorus requirements of food-size channel catfish (Ictalurus punctatus) fed practical diets in ponds," Aquaculture, vol. 154, no. 3-4, pp. 283-291, 1997.

[33] S. Sakamoto and Y. Yone, "A principal source of deposited lipid in phosphorus deficient Red Sea bream," Bulletin of the Japanese Society of Scientific Fisheries, vol. 46, pp. 1227-1230, 1980.

[34] M. Takeuchi and J. Nakazoe, "Effect of dietary phosphorus on lipid content and its composition in carp," Bulletin of the Japanese Society of Scientific Fisheries, vol. 47, pp. 347-352, 1981.

[35] C. Zhang, K. Mai, Q. Ai et al., "Dietary phosphorus requirement of juvenile Japanese seabass, Lateolabrax japonicus," Aquaculture, vol. 255, no. 1-4, pp. 201-209, 2006.

[36] K. Mai, C. Zhang, Q. Ai et al., "Dietary phosphorus requirement of large yellow croaker, Pseudosciaena crocea R," Aquaculture, vol. 251, no. 2-4, pp. 346-353, 2006.

[37] D. I. Skonberg, L. Yogev, R. W. Hardy, and F. M. Dong, "Metabolic response to dietary phosphorus intake in rainbow trout (Oncorhynchus mykiss)," Aquaculture, vol. 157, no. 1-2, pp. 11-24, 1997.

[38] Z. Luo, X. Y. Tan, X. Liu, and W. M. Wang, "Dietary total phosphorus requirement of juvenile yellow catfish Pelteobagrus fulvidraco," Aquaculture International, vol. 18, no. 5, pp. 897-908, 2010.

[39] C. Ogino and H. Takeda, "Mineral requirements in fish. III. Calcium and phosphorus requirements in carp," Bulletin of the Japanese Society of Scientific Fisheries, vol. 42, pp. 793-799, 1976.

[40] P. P. Ketaren, E. S. Batterham, E. Belinda, E. B. Dettmann, and D. J. Farrell, "Phosphorus studies in pigs. 2. Assessing phosphorus availability for pigs and rats," British Journal of Nutrition, vol. 70, no. 1, pp. 269-288, 1993.

[41] T. Åsgård and K. D. Shearer, "Dietary phosphorus requirement of juvenile Atlantic salmon, Salmo salar L," Aquaculture Nutrition, vol. 3, no. 1, pp. 17-23, 1997.

[42] Y. H. Lin and S. Y. Shiau, "Dietary selenium requirements of juvenile grouper, Epinephelus malabaricus," Aquaculture, vol. 250, no. 1-2, pp. 356-363, 2005.

[43] F. Andersen, B. Lygren, A. Maage, and R. Waagbø, "Interaction between two dietary levels of iron and two forms of ascorbic acid and the effect on growth, antioxidant status and some non-specific immune parameters in Atlantic salmon (Salmo salar) smolts," Aquaculture, vol. 161, no. 1-4, pp. 437-451, 1998.

[44] Z. Kucukbay, H. Yazlak, N. Sahin et al., "Zinc picolinate supplementation decreases oxidative stress in rainbow trout (Oncorhynchus mykiss)," Aquaculture, vol. 257, no. 1-4, pp. 465-469, 2006.

[45] Sciences International Inc., Toxicological Profile for White Phosphorus, CAS no. 7723-14-0, US Department of Health and Human Services, Public Health Service, Agency for Toxic Substances and Disease Registry, 1997.

[46] C. C. Lee, J.V. Dilley, J.R. Hodgson, D.O. Helton, and W. J. Wiegand, "Mammalian toxicity of munition compounds. 
Phase I. Acute oral toxicity primary skin and eye irritation, dermal sensitization, and disposition and metabolism," Contract DAMD17-74-C-4073, US Army Medical Research and Development Command, Washington, DC, USA, 1975.

[47] T. Sakai, H. Murata, K. Y. Sekiya, and M. Ukawa, "Effects of dietary lipid peroxides contents on in vitro lipid peroxidation, $\alpha$-tocopherol contents and superoxide dismutase and glutathione peroxidase activities in the liver of yellowtail," Bulletin of the Japanese Society of Scientific Fisheries, vol. 58, no. 8, pp. 1483-1486, 1992.

[48] M. M. Ou, Y. Wang, and W. M. Cai, "Physiological and biochemical changes in Microcystis aeruginosa Qutz. in phosphorus limitation," Journal of Integrative Plant Biology, vol. 47, no. 6, pp. 692-702, 2005. 


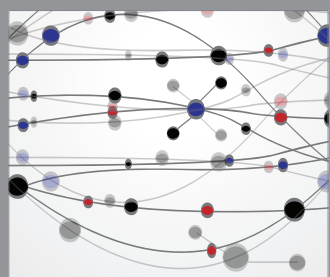

The Scientific World Journal
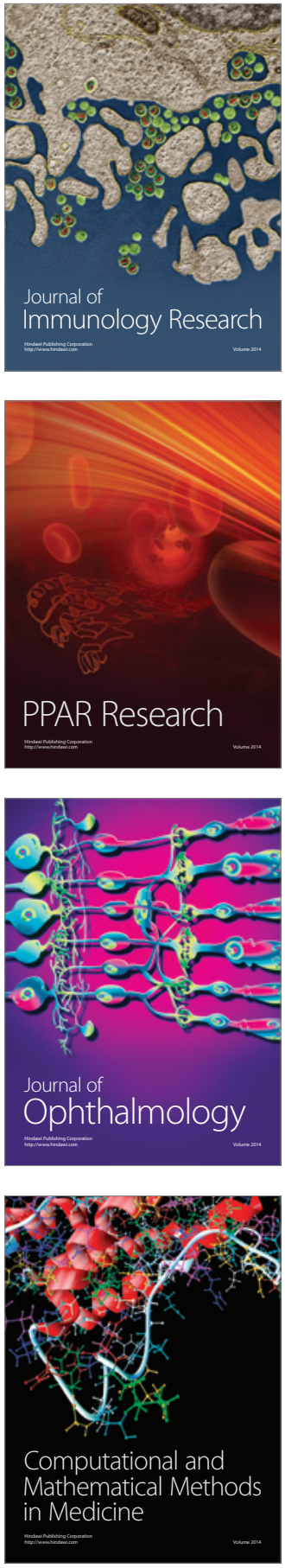

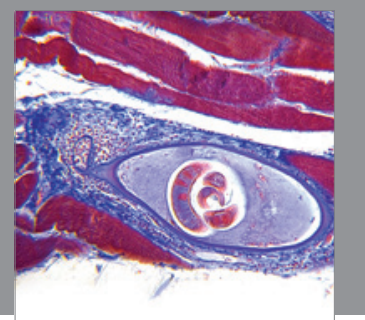

Gastroenterology

Research and Practice
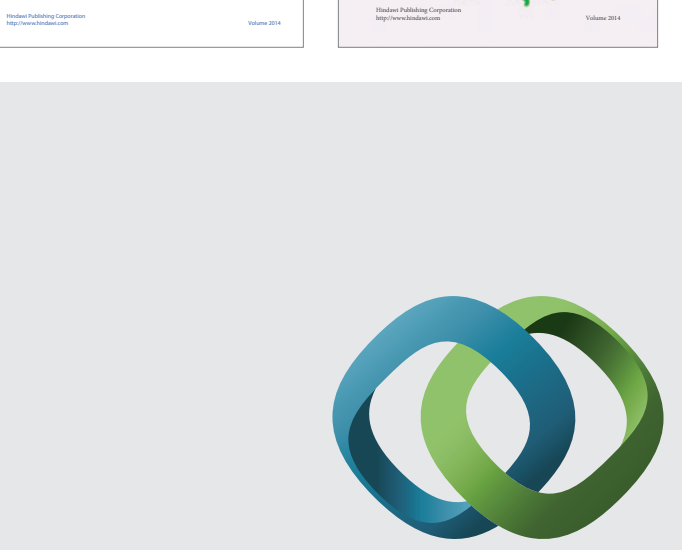

\section{Hindawi}

Submit your manuscripts at

http://www.hindawi.com
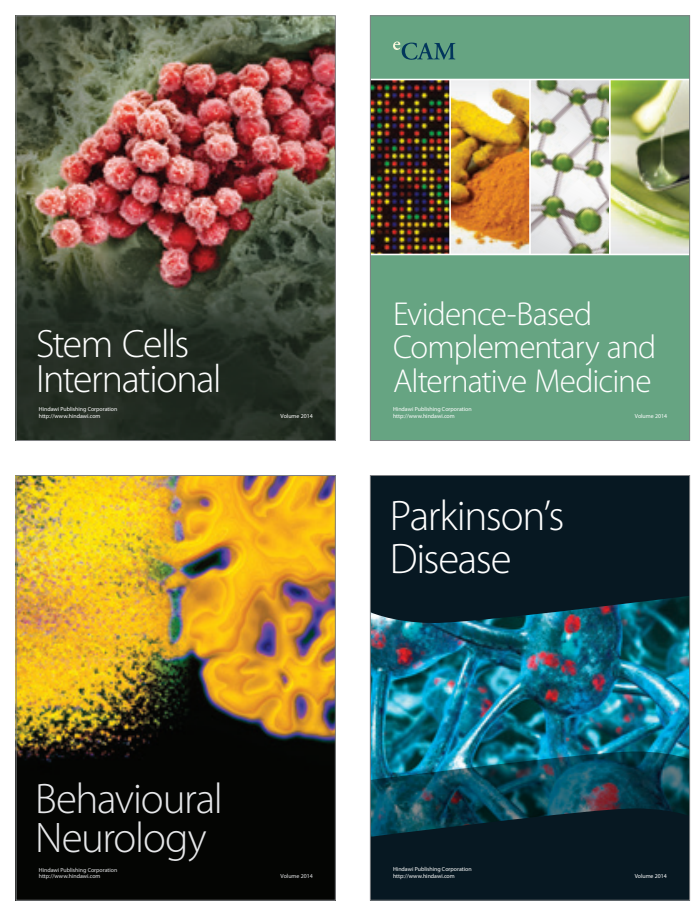

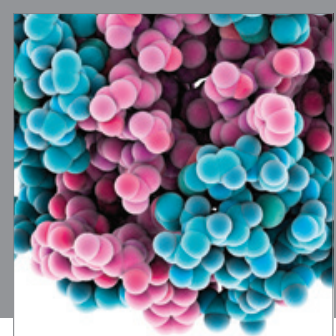

Journal of
Diabetes Research

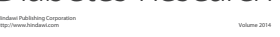

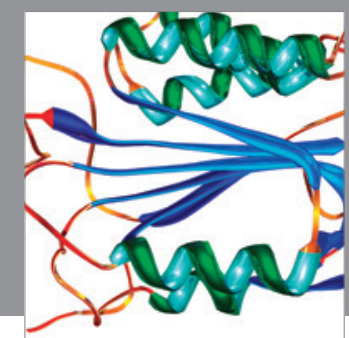

Disease Markers
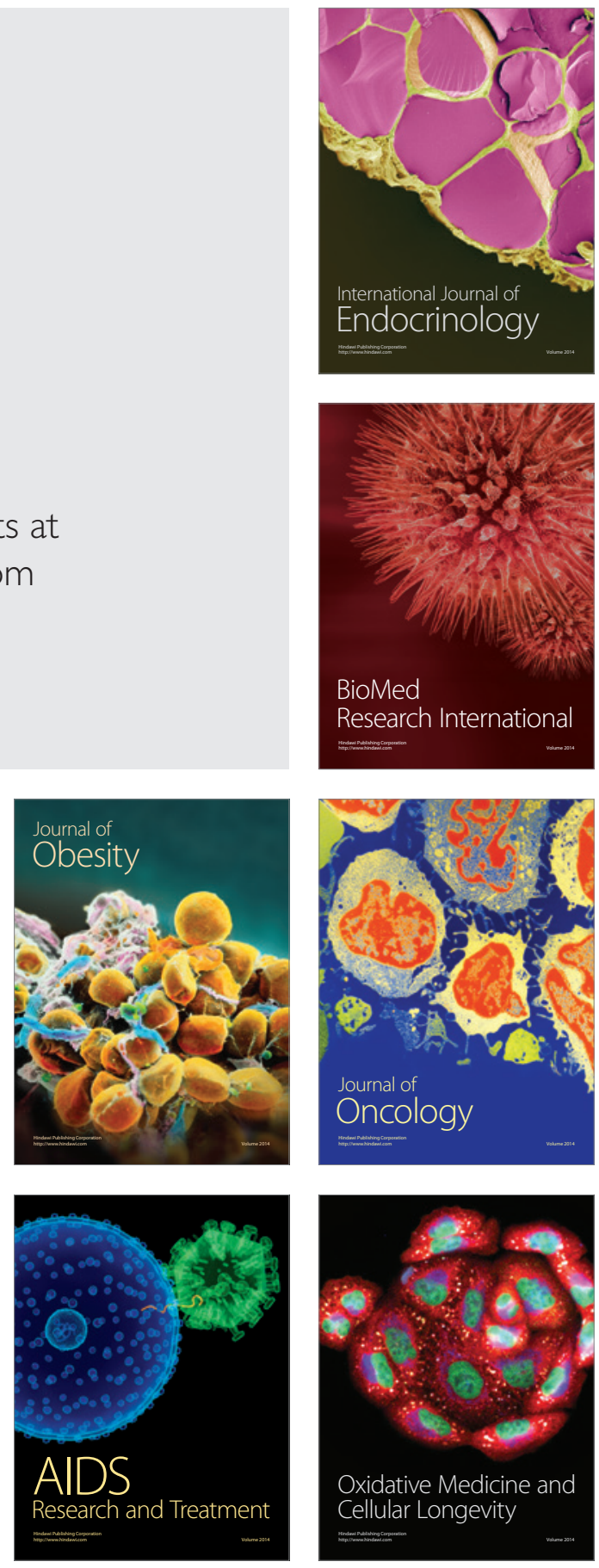